\title{
メソ化合物，プロキラル炭素を含む化合物 からの光学活性体の合成
}

長 尾 善 光*藤 田 榮 -

\author{
Syntheses of Optically Active Substances from the Meso Compounds \\ and the Compounds having a Prochiral Carbon Atom.
}

Yoshimitsu NAGAO* and Eiichi FUJITA*

\begin{abstract}
Recently, studies on the chiral synthesis have been extensively stressed upon. There has been progress in cooperation with the development of highly selective reagents. Useful enzymes $(e . g$. immobilized enzymes), microorganisms, and excellent analytical instruments for spectroscopy and for the chromatography have become available. In this context we reviewed the papers concerned with the syntheses of optically active compounds from the meso compounds and the symmetrical molecules having a prochiral carbon atom. We have dealt only with the compounds possessing functional groups in the same ligands of the symmetrical prochiral molecule.
\end{abstract}

\section{1. はじめに}

最近，有機合成の標的化合物としてマクロライド系， マクロラクタム系, $\beta$ ーラクタム系, ポリエーテル系, ポリペプチド采, 含アミノ糖系の抗生物質ならびに抗が ん剤, プロスタグランジンおよびロイコトリエン系化合 物, 抗がん性含芳香環アルカロイド，抗がん性多核フェ ノール系キノイド誘導体, 生理活性オリゴおよびポリペ プチド, 特定の酳素および核酸, 各種昆虫フェロモンお よび植物ホルモンなどが注目されている.これら生物活 性有機化合物はほとんど不斉炭素を有する光学活性体で あり, これらの光学異性と生物活性との間に密接な相互 関倸がなりたっている ${ }^{1,2)}$ 。すなわちこれらの活性物質 が作用する相手が, 受容体 (蛋白質), 細胞膜 (脂質や蛋 白質などから構成されている), 酵素, 核酸などいずれ も“不斉の場”を有しているものばかりなので, 多少の 柔軟性はあっても基本的に光学異性に関する基質特異性 が現れるのは当然かも知れない。

そこで光学異性体のなかで必要な一方の鏡像異性体だ けを（時には両鏡像異性体を各々独立に）合成するデザ インが必要になってくる。キラルなシントンは従来, (1)

* 京都大学化学研究所

* Institute for Chemical Research, Kyoto University (
純化学的不斉合成，(2)ラセミ体の合成とその光学分割, (3) あ特定のプロキラルな化合物 ${ }^{3)}$ に対する酵素や微生 物による不斉誘導, (4)入手容易な糖, アミノ酸, テルペ ンおよび他の光学活性天然有機化合物の化学変換などに よって得られている。これらキラルシントン獲得法の(1) から(3)に抢いては特定のプロキラル化合物 ${ }^{3)}$ を選択しな ければならない。もちろん，その選択は一般的には標的 化合物に応じて行われている。しかしながら，以後の反 応の展開をも考虑して基質を選択しなければならない。 この基質選択はキラル合成デザインの極めて重要な部分 を占めている ${ }^{4,5)}$ 。

最近筆者らは新しい高選択的不斉誘導法の開発研究の 基本的戦略の一つとして, 対称性をもつ基質分子を選び その対称性を活用する不斉誘導に着目している年, 。し かもメソ化合物ならびにプロキラル炭素を含む対称な化 合物への不斉誘導に焦点を絞った。さらに重要なことは, これらプロキラル対称分子（メソ化合物も含む）の同一 リガンドが官能基を有していることが必要不可欠であ る。なぜなら, 図 1 に示すように適当な官能基変換によ っでエナンチオ選択的反応”, “エナンチオ集合的反応”, ならびに“エナンチオ変換反応”などが可能だからであ る。このような有用な反応の展開はプロキラルな化合物 1 が 2 個の同一の官能基を有寸る対称分子であることに 起因している。図1ではプロキラル炭素を含む対称な化 


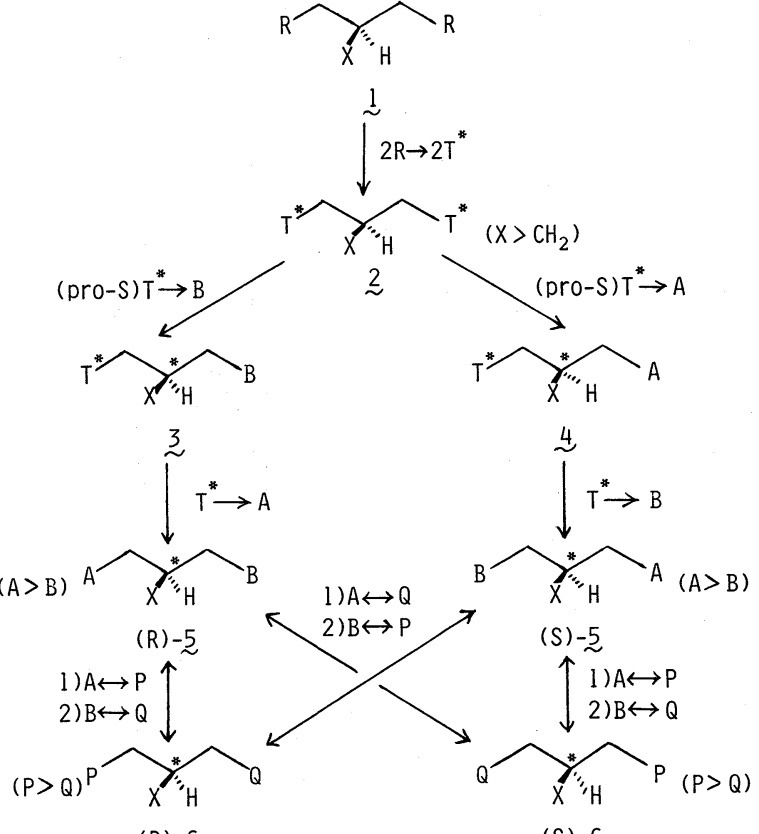

$(R)-\underset{\sim}{\sim}$

(S) $-\underset{\sim}{\sim}$

$\mathrm{A}, \mathrm{B}, \mathrm{P}, \mathrm{Q}, \mathrm{R}, \mathrm{X}$ : 官能基； $\quad \mathrm{C}^{*}$ : 不斉炭素原子;

$\mathrm{T}^{*}$ : キラル官能基 ; $\quad \mathrm{R} \rightarrow \mathrm{T}^{*}$ ：官能基変換 ;

$\mathrm{A} \leftrightarrow \mathrm{P}$ : 官能基相互変換

\begin{tabular}{|c|}
\hline 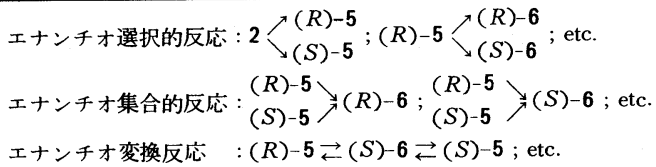 \\
\hline
\end{tabular}

Fig. 1

合物を用いて例示しているが，メソ化合物においても同 様の反応上の展開が可能である。もちろん不斉炭素原子が 1 個の場合にはその炭素原子上で $100 \%$ 立体反転出来 る完全な $\mathrm{S}_{\mathrm{N}} 2$ 型反応が可能であれば対称分子で無くて も“エナンチオ変換反応” は可能であるが，官能基いか んによってはなかなか困難である。最近, 高野, 小 笠原 $ら^{6)}$ は 1 個の不斉炭素原子上の立体化学を完全に反 転させる手法によりD-マンニットールから導いた $(R)-$ 1-ベンジルグリセロールの $(S)-1$-ベンジルグリセロー ルへの“エナンチオ変換反応”に成功している（図2）。 むろん, 光学活性天然有機化合物の化学変換によってキ ラルシントンを獲得する場合でも, 光学活性な 5 および 6 のような潜在的に対称性を有する分子を基質として選 択した方が図 1 に示してある反応の展開が適用されるの で有利である。たとえば津田ら ${ }^{7)}$ は $\mathrm{D}-$ マンニットール から誘導される“潜在的対称分子” $(R)-2,3-O-イ ソ フ ゚ ~$
ロピリデングリセロアルデヒドを出発原料とし適当な官 能基変換だけで両鏡像異性体を“エナンチオ選択的”に 巧みに合成（図3）しているが，本合成は真にこの概念 に該当する。また, 光学活性天然有機化合物の化学変換 によってキラルシントンを得る場合に着目すべき基質の もう一つの対称要素として $\mathrm{C}_{2}$ 対称軸を有するキラルシ ントンを得るデザインも重要である。

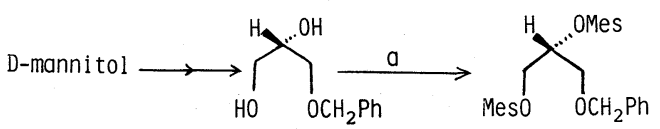

(R)
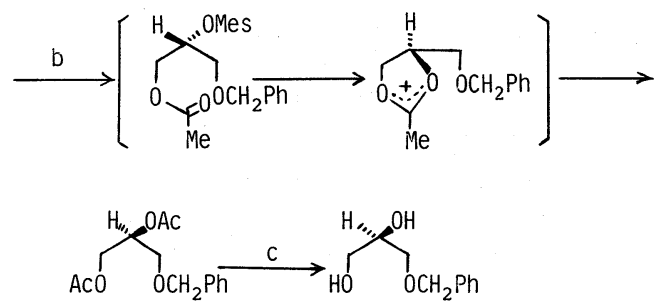

(S)

$a: M e s C l, P y r ; b: A c O K, \mathrm{AC}_{2} \mathrm{O}: c: \mathrm{K}_{2} \mathrm{CO}_{3}, \mathrm{MeOH}$

Fig. 2

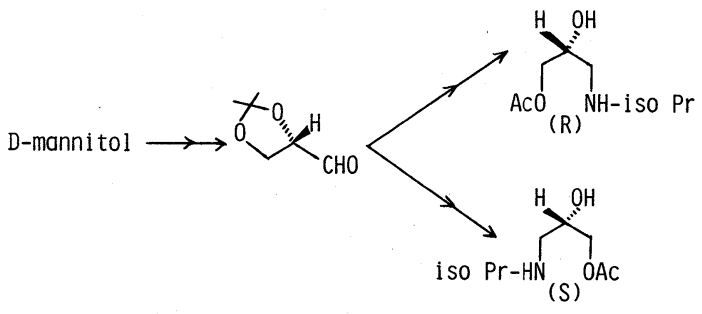

Fig. 3

以上，対称分子を基質として選択した場合の不斉合成 戦略における有利性の概略を述べた。これを背景として, 本稿では特に同一リガンドに官能基を有するメソ化合物 ならびにプロキラル炭素を含む対称な化合物への不斉誘 導に限って酵素および微生物による変換反応と純化学的 方法に大別対比しながら過去の研究業績から最新の研究 成果にわたり適宜選択して概説したい。

\section{2. プロキラル炭素原子を含む対称分子への不斉誘導}

2.1. 酵素および微生物を活用する不斉誘導 Cohen $5^{8)}$ は $\alpha$ アアトアミドマロン酸ジェチルエステ ル（7）を $\alpha$-キモトリプシンを用いリン酸緩衝液 ( $\mathrm{pH}$ 7.8) 中部分加水分解し光学活性なモノエステルを得ている。 
本半加水分解反応について基質と酵素両濃度に一次の速 度論的データが報告されている。しかしながら, 同様反 応条件下でジェステル 8 および 9 は部分加水分解されたが 非立体選択的にモノエステルを与え，化合物 10 は全く 加水分解されなかった。さらに, Cohen ら ${ }^{9)}$ は各種 3 置換グルタル酸ジエステルの $\alpha$-キモトリプシンによる 半加水分解を試み, 高化学収率 (以後図中, 略語 cy 用いて示す), 高立体選択的にそれぞれ対応する $R$ 配置 のモノェステル体 11〜13 のみを得ている（図4）。

$$
\text { a: } \alpha \text {-chymotrypsin, } \mathrm{NaH}_{2} \mathrm{PO}{ }_{4}(\mathrm{pH} \quad 7,8)
$$

Fig. 4

Leuthardt $\check{ら}^{10)}$ は馬肝臓アルコール脱水素酵素 (HLADH) によるグリセロール(14) の酸化反応を行っ たところ pro- $S$ 水酸基のみを酸化しもっぱら L-グリ七 ロアルデヒド (15) を得ている (図 5 )。Jones ら ${ }^{11)}$ は本 反応をさらに発展拡大し 3 置換ペンタン-1,5-ジオール 16 19 を触媒量の NAD+ 補酵素の再利用下に FMN を 使用し HLADH にて同一リガンド $\left(-\mathrm{CH}_{2} \mathrm{OH}\right)$ のエナ ンチオトピックな酸化反応（場合によってひき続いて $\mathrm{Ag}_{2} \mathrm{O}$ による酸化を行ら）を行ったところ，いずれも優 先的に pro- $S$ 水酸基が酸化され，それぞれ対応する光 学活性ラクトン 20 23 を得ている。化学収率は全て良 好であったが, 成績体の光学純度 (以後図中, 略語 op として示す)は基質によってかなり異なる。なお, Jones らは本酵素反応の立体選択的不斉認識について Diamond Lattice Section 解析法を活用して議論している。

$\operatorname{Sih} \check{5}^{12)}$ は $\beta$-ヒドロキシー $\beta$-メチルグルタル酸ジメ チルエステル (24) を $0.1 \mathrm{M}$ リン酸緩衝液中ブタ肝臓エ

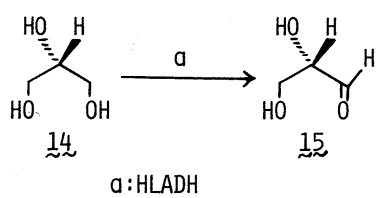

Fig. 5
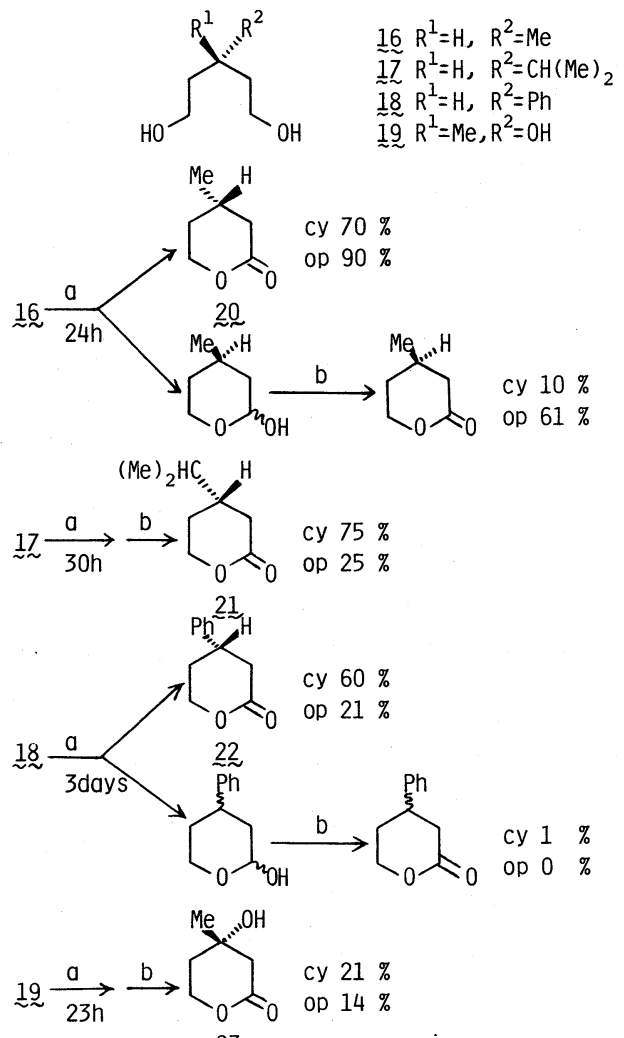

23

$\mathrm{a}: \mathrm{HLADH}, \mathrm{NAD}^{+}$recycling, $\mathrm{pH} 9,20^{\circ} \mathrm{C} ; \mathrm{b}: \mathrm{Ag}_{2} \mathrm{O}$

Fig. 6

ステラーゼ (PLE) で処理し, 高い光学純度の半加水分 解成績体 25 を $62 \%$ の化学收率で得た。25 の絶対配置 と光学純度は $(R)$-メバロノラクトン $(26)$ 一変換する ことによって決定された（図 7)。メバロノラクトン 合成のもう一つの方法として, Sih ら ${ }^{12)}$ は文献既知の微 生物 Flavobacterium oxydans を用いてトリオール(300

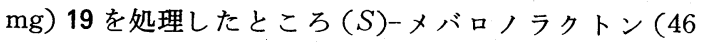
$\mathrm{mg})(23)$ を得た（図8)。さらに，同氏らは $(R S)-$ メ バロノラクトン $(120 \mathrm{mg})$ を F. oxydans で処理したとこ ろ $(S)$-メバロノラクトン $(44 \mathrm{mg})[\alpha]_{\mathrm{D}^{26}}+15^{\circ}(\mathrm{EtOH})$ を得た。本実験結果は $(R)$-体 26 が選択的に活用され 
たことを示唆している。いずれにせよ 19 から $(S)$-体 23 への F. oxydans による酸化経路については次に示すよう な(1), (2)の仮説が考えられる。すなわち，(1) F. oxydans は優先的に 19 の pro- $S \mathrm{CH}_{2} \mathrm{OH}$ 基を酸化して $(S)$-体 23 を与える。(2) F. oxydans は 19 の pro-Rならびに pro- $S$ 両方の $\mathrm{CH}_{2} \mathrm{OH}$ 基を酸化し $(R S)$-メバロノラク トンを与える。次いで $(R)$-体 26 のみが選択的にその 生体組織によって使用され，その結果残った $(S)$-体 23 が単離された。これらのいずれが正しいかはさらに詳細に 検討する必要がある。な拀，太田ら ${ }^{13)}$ も Gluconobacter species による 1, 5- ジオール 19 や 2-置換プロパン-1, 3ジオール類のエナンチオ選択的酸化反応を報告している。
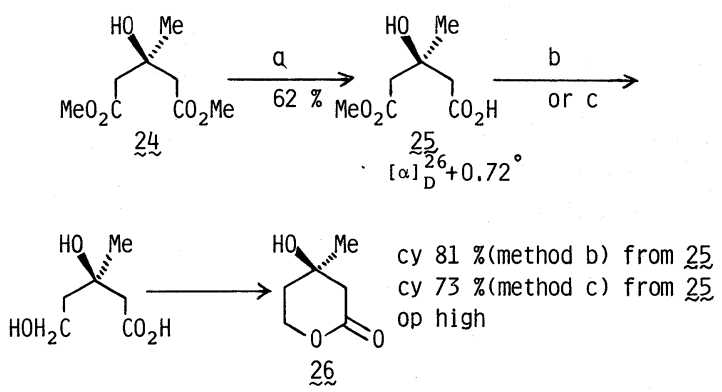

a:PLE, phosphate buffer ( $\mathrm{pH} 8$ ), $25^{\circ} \mathrm{C}, 3 \mathrm{~h} ; \mathrm{b}: \mathrm{LiBH}_{4}$ : c: $\mathrm{Na}, \mathrm{NH}_{3}-\mathrm{EtOH}$

Fig. 7

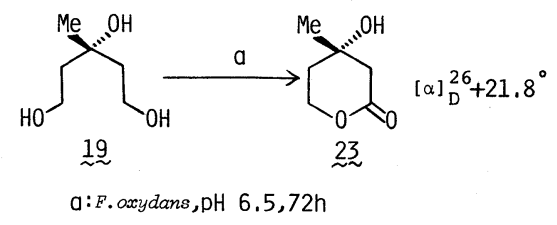

Fig. 8

大野ら ${ }^{14)}$ は酵素化学的アプローチによる生物活性物質 の合成研究の一環として, カルバペネム誘導体のキラル 合成の重要原料である光学活性 4-置換-2-アゼチジ, ン 33 の合成を 3 -ベンジルオキシカルボニルアミノグル タル酸ジメチルエステル (30)の酵素反応成績体を活用 して成功している（図9）。まず，同氏らは 3-アミノグ ルタル酸ジメチルエステル (27) の PLE 半加水分解を試 みた。その結果, $94 \%$ という高化学收率でモノエステ ル 28 を得たが, 28 の光学純度は極めて低く, さらにそ の立体化学が望ましいものでは無いことなどが以後の変 換反応から明らかとなった。すなわち，28 $8 \mathrm{MeCN}$ 中 $\mathrm{Ph}_{3} \mathrm{P}-(\mathrm{PyS})_{2}$ 系反応剂で処理すると $82 \%$ の収率で 2 -

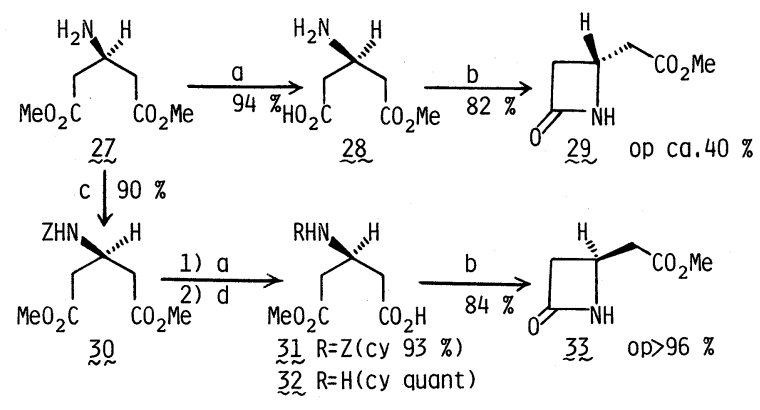

a:PLE, phosphate buffer ( $\mathrm{DH} 8), 25^{\circ}, 1.5 \mathrm{~h} ; \mathrm{b}: \mathrm{Ph}_{3} \mathrm{P}-(\mathrm{PyrS})_{2}$, MeCN, reflux; $c: \mathrm{PhCH}_{2} \mathrm{OCOCl}, \mathrm{Et}_{3} \mathrm{~N} ; \mathrm{d}: \mathrm{H}_{2}, \mathrm{Pd}-\mathrm{C}$

Fig. 9

アゼチジノン 29 を得た。29の絶対配置 $(R)$ および光 学純度（約 $40 \%$ ）は L-アスパラギン酸から別途に合成

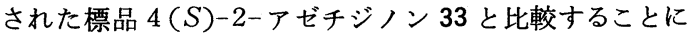
よって決定された。なお， 28 の低い光学純度は 27 の酵 素無しでも本反応条件下で部分加水分解 (約 $30 \%$ ) され ることに起因することが明らかにされた。そこで，同氏 らは 27 のアミノ基をベンジルオキシカルボニル $(Z)$ で 修飾した化合物 30 をPLE と同様条件下にインキュべ ートした。その結果, 27 の場合と全く逆の PLEによる 不斉認識により $3(S)$-モノエステル 31 が $93 \%$ の高化 学収率で得られた。31 は, 置換基 $Z$ の脱離後, 28 の場 合と同様の環化反応に付され単環性 $\beta$-ラクタム 33 人 $84 \%$ の化学収率で変換された。33 の光学純度 $(\mathrm{op}>$ $96 \%$ ）は極めて高く，しかも光学活性カルバペネム誘導 体全合成原料として望ましい絶対配置を有している。上 述のように，同一酵素による不斉認識が基質 27 のプロ キラル炭素原子上のアミノ基がそのままの場合と $Z$ 基で 修飾した場合とで逆になるという知見は注目に值し，こ の種の生産的酳素工学領域に極めて示唆に富んだ情報を 提供したことになる。33 はチェナマイシン（34）の合成 中間体 35 やアスパレノマイシン-C (36) の全合成に活 用され，31 は(ー)-カルペチマイシンーA (37) の全合
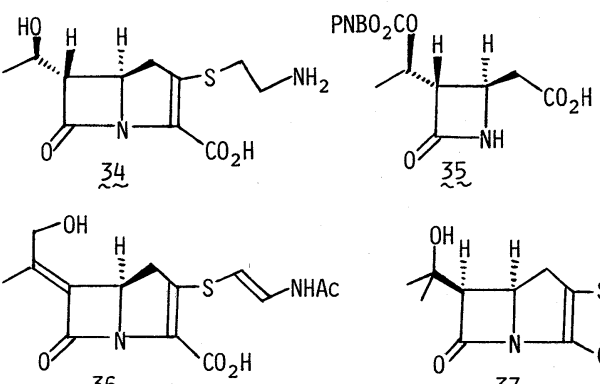

36

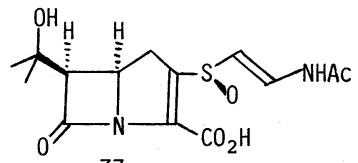

37 
成に利用されている。

2. 2. 純化学的方法による不斉誘導 3-置換グルタ ル酸誘導体は応用範囲の広いキラルシントンの前駆体と して格好な化合物である。対称な 3-置換グルタル酸ジ エステルのプロキラル中心についたエナンチオトピック な置換基の一方だけの置換基 (エステル) の高選択的変 換は，筆者らが純化学的新手法を開発するまでは前述の ようにもっぱら酵素, 微生物のみによって行われていた。 この種の対称なプロキラル炭素を有するグルタル酸誘導 体への化学的手法による不斉誘導として, 筆者らが開発 する以前に 2 例ほど報告があるがいずれも不斉収率 (ジ アステレオ異性体過剩率）の点で全く不満足である。す なわち, Schwartz ら ${ }^{15)}$ は $\beta$-フェニルグルタル酸無水

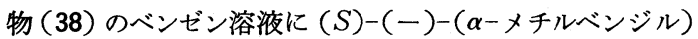
アミン（39）の当モル量を加えて反応させ $60: 40$ の比か らなるジアステレオ異性体を得ている（図 10)。Cohen ら ${ }^{16)}$ は同様の酸無水物 38 を lーメントール(40)を用い て $155^{\circ} \mathrm{C}$ でアルコール分解し, ジアステレオ異性体の l-メンチルモノェステルを $54: 46$ の比で得ている(図 10)。
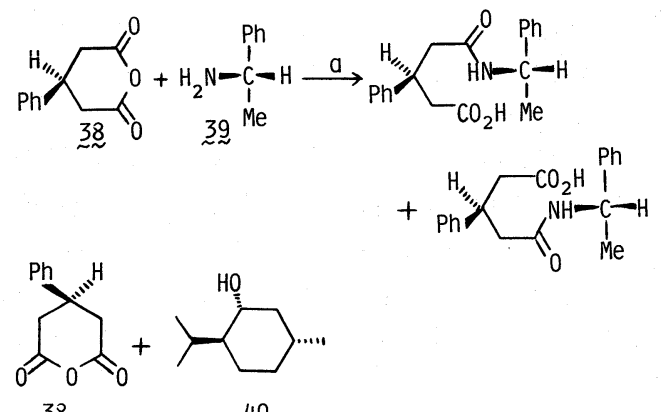

38

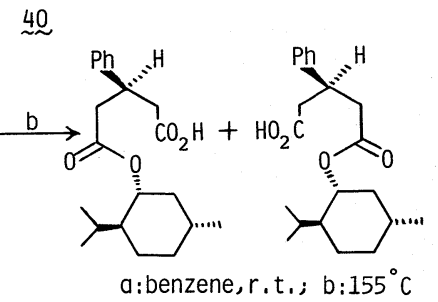

Fig. 10

さて，筆者らによる高選択的な新手法について述べる。 その新不斉合成の分子設計に関する基本戦略は次の通り である。標的化合物としては醭素および微生物変換での み高エナンチオ選択的不斉誘導が可能であろうと考えら れる対称なプロキラルジカルボン酸, 3-メチルグルタル酸 (44), メソ-2, 4-ジメチルグルタル酸 (3.2. 参照), メソー 5- ルルボルネニレンーエンド-2, 3- 酒酸 (3. 2. 参照), そ して準メソ化合物のシスー4-シクロヘキセニレンー $1,2-シ ゙$
眽酸（実際は配座変換による鏡像異性体の等量混合物） (3.2. 参照)などを選んだ。このような化合物を選択し たのは次の理由による。すなわち，(1)酥素反応を純化学 的な簡単な手法で達成したい。(2) 2 個の同一キラル補助 剤を活用する対称分子の不斉認識に関する新概念を確立 したい。(3)ただ一種のキラル補助剤を使用することと官 能基変換だけで“エナンチオ選択的反応”, “エナンチオ 集合的反応”，ならびに“エナンチオ変換反応”などのデ ザインが容易に出来る。(4)キラル補助剤の結合も脱離も 容易である。

反応の遷移状態における分子の自由回転規制にはへテ 口原子との共役によってかなり強い双極子能率を示すチ オカルボニル基とカルボニル基間の双極子一双極子反発 を活用した（図11）。キラル補助剤としては入手容易な アミノ酸，Lーシステインから導かれたメチルエステル 塩酸塩 (41) と二硫化炭素から簡単に合成され（図 12), 不斉環境の二分性といら観点から有利である比較的平面 的な脱離機能性複素 5 員環, $4(R)$-メトキシカルボニ ル-1,3-チアジリジンー2-チオン [以後 $4(R)$-MCTT と略] (42) を選んだ。この4 $(R)-\operatorname{MCTT}(42)$ ならび にその 3-アシル化体 43 はともに強度な紫外線吸収を示 すことから, 高速液体クロマト (HPLC) 分折に適して いる。以上述べてきたキラルデザインに至る基本的戦略

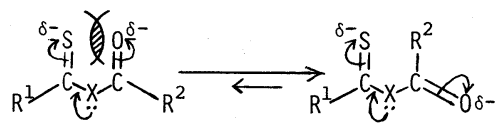

Fig. 11

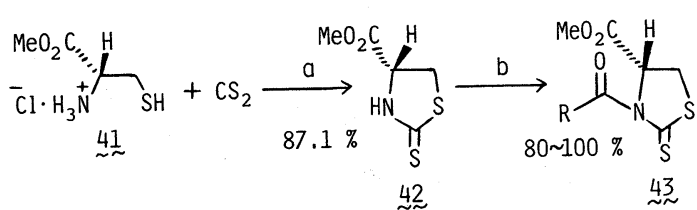

$a: \mathrm{Et}_{3} \mathrm{~N}, \mathrm{CH}_{2} \mathrm{Cl}_{2}, r, t, ; b: \mathrm{RCOCl}_{1}, \mathrm{Et}_{3} \mathrm{~N}, \mathrm{CH}_{2} \mathrm{Cl}_{2}, r, t$.

Fig. 12

は一貫して実施してきた含硫黄脱離基を活用する有機合 成研究 ${ }^{17)}$, なかでも機能性複素 5 員環 3-アシルー1,3チアジリジンー2-チオン (ATT) を利用する各種モニタ 一反応 (各種 ATT に対する求核反応が反応完了と同時 にATTの黄色が消失するので反応をモニター出来る) ならびにその生理活性アミド型天然物全合成への応用研 究での経験から導き出されたものである ${ }^{18)}$ 。ここでは 3メチルグルタル酸 (44) の 2 個の同一置換基の高位置選 択的区別について述べる。その全反応操作は図 13 に示 
した通りである ${ }^{19)}$ 。

すなわち，3-メチルグルタル酸 (44) と二分子の 4 $(R)-\mathrm{MCTT}$ (42) とをピリジン中 DCCの存在下に縮 合すると好収率でジアミド 45 が得られる。45の “ $\mathrm{Nu}^{1} "$ 処理によって得られた化合物 46 と 47 はジアステレオ異 性体の関係なので両異性体は分離可能である（これは酵 素反応などに拉けるエナンチオ選択的プロセスに比べ有 利である)。化合物 46 あるいは 47 は続く “ $\mathrm{Nu}^{2} "$ 処理に より各々対応する鏡像異性体関倸にある 48 および 49 に 導かれ, 図 13 に示した全反応操作によって 3-メチルグ ルタル酸 (44) の同一リガンドを区別したことになる。 通常, 44 の pro-S リガンド $\left(\mathrm{HO}_{2} \mathrm{CCH}_{2}-\right)$ と pro- $R$ リ

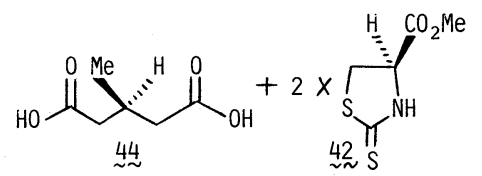
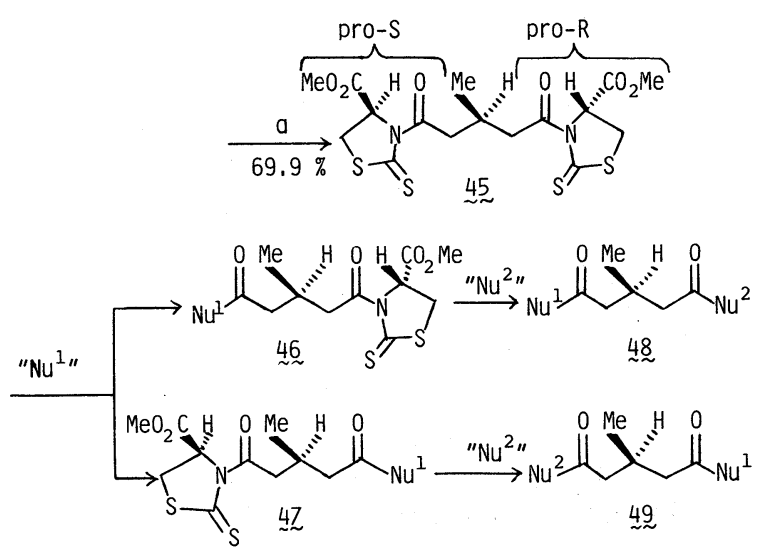

a:DCC, pyr, r, t.; "Nu" ${ }^{1} ", " \mathrm{Nu}^{2}$ " nucleophile

Fig. 13

ガンド $\left(\mathrm{CH}_{2} \mathrm{CO}_{2} \mathrm{H}\right)$ を化学的に区別することは困難で ある。しかしながら光学活性ジアミド 45 では pro-S $S$ ガンドと pro- $R$ リガンド中の両カルボニル基の周辺の 立体環境は異なる。すなわち，アミドカルボニル基とチ オカルボニル基間の双極子間反発ならびに pro- $S$ およ $ひ ゙$ pro- $R$ 基間の立体反発により自由回転可能な立体配 座が低温下で 45 に示すようなW型あるいは若干ねじれ たW型に規制されるはずである。もしそうであるなら， 求核剂 “ $\mathrm{Nu}^{1}$ ” は攻撃可能な 4 箇所 (pro-S 側のカルボニ ル基の $\alpha$-と $\beta$-面ならびに pro- $R$ 側のカルボニル基の $\alpha$-と $\beta$-面)のうち, 最も立体障害の少ないpro- $S$ 側の アミドカルボニル基に対する $\alpha$-面から優先的に攻撃す ることが予測された。事実, ジアミド 45 のX 線結晶解
析の結果，その結晶構造はわずかにねじれたW型コンホ メーションを示していることが明らかとなり，筆者らの 作業仮説を強く支持した。さて, その実験であるが，ジ アミド 45 を $\mathrm{CH}_{2} \mathrm{Cl}_{2}$ 中 $-30^{\circ} \mathrm{C}$ で, 1 モル当量のピペリ ジンで処理したところ, 好化学収率 $(73.6 \%)$ かつ, 高 選択的に主成績体 46 a (46: $\left.\mathrm{Nu}^{1}=-\mathrm{N}\right)$ および副成績 体 47a (47: $\left.\mathrm{Nu}^{1}=-N\right)$ が得られた $(46 \mathrm{a}: 47 \mathrm{a}=88: 12$ HPLC 分析)。両ジアステレオ異性体はシリカゲルカラ ムクロマト上で分離された。

主成績体 46 a の立体化学は，3 位の絶対配置既知の

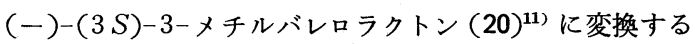
ことによって化学的に立証された（図 14)。これにより 46 a 3 位の絶体配置が $R$ 配置であることが確立され た。さらに，46aを(S)-(一)-( $\alpha$-メチルベンジル) ア ミンで処理して得た成績体 48 a の X 線解析からも $46 a$ の立体化学の証明がなされた（図 15)。副成績体 47a の立体化学は 48 a の対掌体 49 a に導くことによって確 立された（図 16 )。

化合物 $46 \mathrm{a}$ の有用性を検討する目的で，いくつかの 求核剤 “ $\mathrm{Nu}^{2}$ ” [各種アミン，ナトリウムチオレート，ア
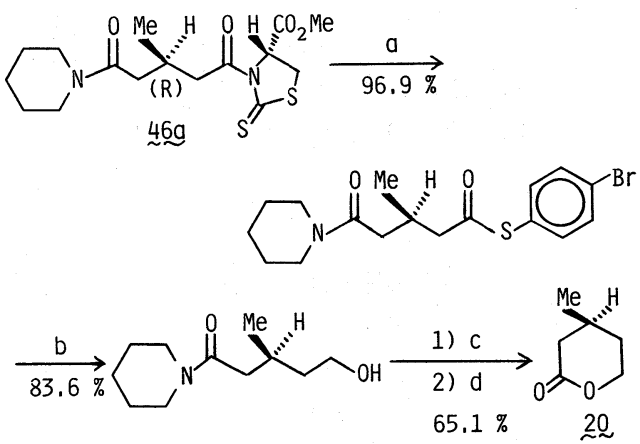

$a: H S-O-B r, N a H, T H F ; b: N^{-} B_{4}$, aq. THF; $c: 6 N-H C l$, reflux; d:azeotropically reflux, benzene

Fig. 14

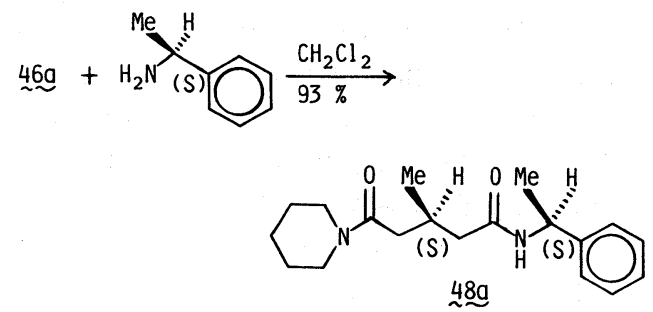

Fig. 15 


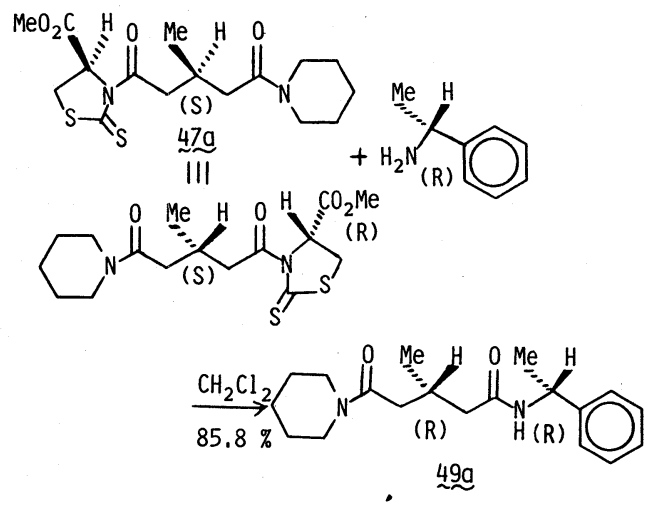

Fig. 16

ルコール $\left(+\mathrm{AgClO}_{4}\right)$, ジメチルオキソスルホニウムメ チリド, ナトリウムジェチルマロネート）との反応を行 い, 鏡像異性的に純粋な各種成績体 $48 \mathrm{~b} \sim 48 \mathrm{~g}$ が高化学 収率で得られた。これらの反応は $46 \mathrm{a}$ の黄色が反応の 終結と同時に無色になることによりモニターされ得る。

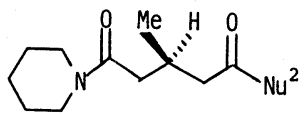

48 $\mathrm{Du}^{2}=-\mathrm{NHCH}_{2} \mathrm{Ph} 98.1 \%$ $48 \mathrm{Cu}^{2}=-\mathrm{S}-\mathrm{t}-\mathrm{Bu} \quad 85.4 \%$ $48 \mathrm{~g} \mathrm{Nu}=-\mathrm{OCH}_{2} \mathrm{CH}_{2} \mathrm{Ph} 84.1 \%$ 48. Nu ${ }^{2}=-\overline{\mathrm{C}}-\mathrm{H}_{-}^{+}(\mathrm{Me})_{2} 85.4 \%$

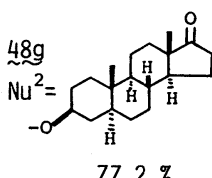

48f $\mathrm{Nu}^{2}=-\mathrm{CH}_{2}\left(\mathrm{CO}_{2} \mathrm{Et}\right) 98.5 \%$

このようにして選択性の高い，収率の良い，緩和な条 件下での簡便な非酵素的不斉誘導法を開発したが，本新 手法の特徴と利点を次に示す。すなわち，本法は酵素反 応と異なり基質の方にキラリティーをもたせたデザイン が特徴的であり，しかも全反応行程途上（図13）必ず ジアステレオ選択的プロセスを経過することから，両ジ アステレオ異性体を分離することが可能であり，従って それらの異性体から導かれる両鏡像異性体は全く純粋で ある。また, 本化学的方法ではキラル補助阂の鏡像異性 体の一方を選択することによって任意にエナンチオ選択 的に目的とする成績体を合目的的に得ることが出来るが， 酵素, 微生物を用いる方法では一般的に不可能であり， 試行錯誤的により適切な酵素, 微生物などを探索するか, 基質の適当な化学的修飾などを行ったうえで再検討しな

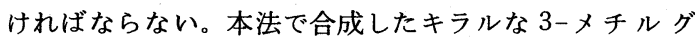
ルタル酸誘導体は生物活性天然物全合成の有効なキラル シントンとして利用されるであろう。また，本法は 3 位
炭素原子上にメチル基以外の置換基の付いたグルタル酸 を基質として選択することにより，ますますその有用性 を増大するものと信じる。

吉川ら ${ }^{20)}$ は 3 種類の 3 置換グルタル酸無水物を $\mathrm{Et}_{3} \mathrm{~N}$ およびキラルな 2 価のルテニウム錯体, $\mathrm{Ru}_{2} \mathrm{Cl}_{4}[(-)$ DIOP $]_{3}[(-) D I O P$ : (一)-2,3-O-isopropylidene-2, 3 -dihydroxy-1, 4-bis (diphenylphosphino) butane] 触 媒の存在下水素添加することにより光学活性な $(R)$-ラク トンを得ている（図17)。酵素反応によるジオールの酸

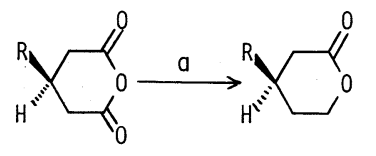

$R=$ Me cy $61 \%$, op $19.4 \%$ $R=i-\operatorname{Pr}$ cy $79 \%$, op $5.4 \%$ $\mathrm{R}=\mathrm{Ph}$ cy $56 \%$, op $20.0 \%$

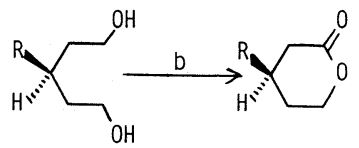

R=Me cy $66 \%$,op $10.8 \%$ $R=i-\operatorname{Pr}$ cy $60 \%$, op $15.2 \%$

$\mathrm{a}: \mathrm{H}_{2}\left(10 \mathrm{Kg} / \mathrm{Cm}^{2}\right), \mathrm{Ru}_{2} \mathrm{Cl}_{4}\left[(-) \mathrm{DIOP}_{3}, \mathrm{Et}_{3} \mathrm{~N}\right.$, toluene, $100^{\circ} \mathrm{C}, 5 \mathrm{~h}$; b: $\mathrm{Ru}_{2} \mathrm{Cl}_{4}\left[(-) \mathrm{DIOP}_{3}, \mathrm{Et}_{3} \mathrm{~N}\right.$, toluene, $110^{\circ} \mathrm{C}, 10 \mathrm{~h}$

Fig. 17

化 (2.1. 参照) の方が光学収率は高いが，遷移金属錯体 触媒を活用した数少ない一例として注目されよう。また， 同氏ら ${ }^{21)}$ は $\mathrm{Ru}_{2} \mathrm{Cl}_{4}[(-) \mathrm{DIOP}]_{3}$ 触媒, $\mathrm{Et}_{3} \mathrm{~N}$ の存在下 トルェン中加熱還流下に若干のジオール類のエナンチオ 選択的脱水素反応を行い, 光学活性な $(R)$-ラクトンを 低光学収率ながら得ている。

西独シェーリング社研究グループ22) と米国ホフマン・ ラ・ロッシュ社研究グループ23) は両者ほぼ同様の簡便 な高エナンチオ選択的な環化法を開発しステロイド CD 骨格の不斉的構築に成功している。すなわち, Wiechert ら ${ }^{22)}$ は各種アルキルビニルケトンと各種 1,3-ジケトン類 から導いたプロキラルなシクロペンタン-1, 3-ジオン誘 導体 50 およびシクロへキサン-1,3-ジオン誘導体 51 を 有機酸あるいは無機酸水溶液の存在下, 光学活性アミ, 酸あるいは光学活性アミンを用いて環化反応を行い，各 々対応する各種光学活性二環性エノン類を得ている。図 18 には光学収率の高かった 2 例, $50 \mathrm{a} \rightarrow 52$ ならびに $51 \mathrm{a} \rightarrow 53$ の不斉環化反応を紹介しておく。一連の実験 から，(S)-アミノ酸および $(S)$-アミンを用いれば $(S)$ 配置の二環性成績体を与える不斉認識のもとに反応が進 行し,さらに原料, アミン成分, 溶媒, ならびに酸に依 存することが明らかとなった。 


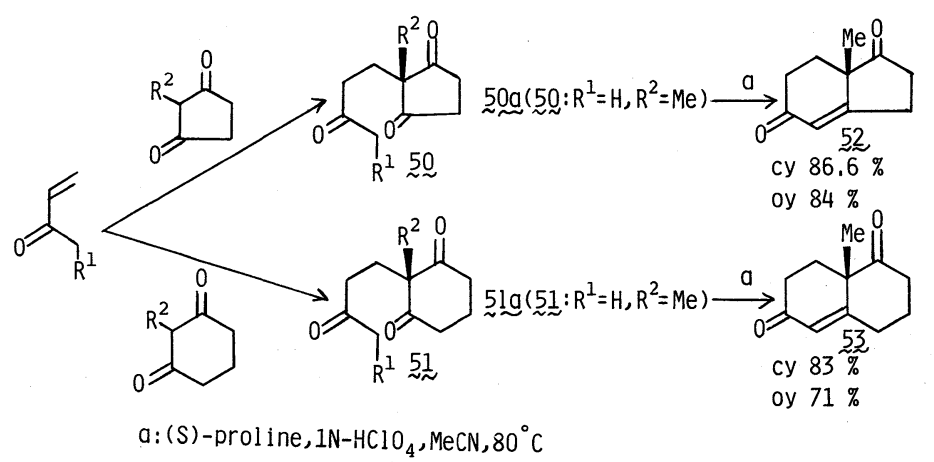

Fig. 18

Hajos ら ${ }^{23)}$ も類似の不斉環化法（図 19）を開発した のであるが，彼らが $(S)-フ^{\circ}$ リンを環化反応のキラル な触媒として選択寸るに至ったのは, ピロリジンと (十)10ーカンファースルホン酸を利用した類似の不斉環化反 応に基づいて考察した次の理由による。(1) $(S)$-プロリ ンは光学活性ピロリジンと見なされ，さらにピロリジン一 (+)-10-カンファースルホン酸系と異なり不斉炭素原 子は酸性官能基に隣接した形式で同一分子内に存在する。 (2) $(S)$ プロリンの不斉炭素原子は 5 員環内にあり，環 状の固定化された不斉環境下での不斉認識はその認識度 を増強するという経験則に合致する。(3)同一置換基を効 果的に区別するためには光学活性反応剂は基質の対称化 合物に対して 1 点以上で接触すべきである。 $(S)$-プロ リンは二官能性であり真にこれにかなっている。

かくして, 50 aを $\mathrm{MeCN}$ 中 1 モル当量の $(S)$-プロ リンと 6 日間処理することによりケトール $(+)-54$ が $97.3 \%$ の化学收率で得られた。エーテルから再結晶す ることによって光学的に純粋な (+)-54 となる。粗製 ケトール 54 は脱水反応により, 定量的に粗製のエノン (+)-52 を与えた。その光学純度は $85.6 \%$ であったが， 紫外線吸収スペクトルによる $(+)-52$ の化学的純度の 補正から得られた $(+)-52$ の真の光学純度は $97.1 \%$ と
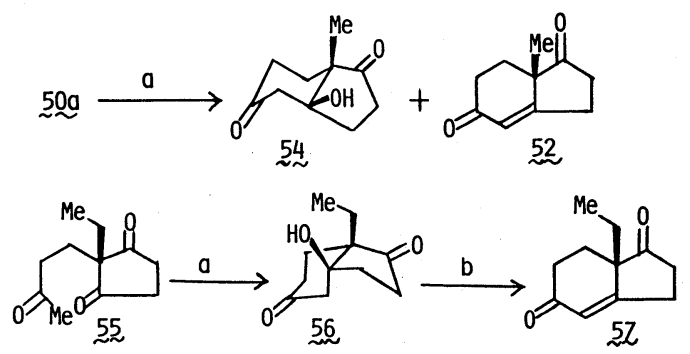

a: (S)-prollne, MeCN or DMF; b: TsOH, benzene, reflux

Fig. 19
計算された。なお， 50 a の環化反応を DMF 中 $3 \%$ モ ル当量の $(S)$-プロリンを用いて行ったところ，20 時間 で（+）-54のみを選択的に，かつ定量的に与えた。その 光学純度は $93.4 \%$ であった (図 19)。同様に 50 a の同 族体 55 を DMF 中 $30 \%$ モル当量の $(S)$-プロリンを用 いて処理したところ，光学的に純粋なケトール(+)-56 が $71 \%$ の収率で得られた。56の加熱還流下での脱水反 応はェノン (+)-57 を定量的に与えその光学純度は 99.5 $\%$ を示した (図 19)。本不斉環化反応の機構として 2 つの機構が考えられているが，より好ましいものとして 提呾されている方を図20に示寸。な扔，本不斉合成は $(S)$-プロリンが酵素の役割を演ずる生体系反忘の簡単 なモデルの一例として注目に值する。

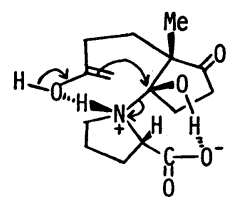

Fig. 20

\section{3. メソ化合物への不斉誘導}

3.1. 酵素および微生物を活用する不齐誘導 Jones ら ${ }^{24)}$ は各種脂肪族メソ型 1,4-および 1,5-ジオール類の 馬肝臓アルコール脱水素酵素 (HLADH) 触媒存在下に 打ける立体選択的酸化反応を試みたところ, 全て $(S)-$ キラル中心に付いた $-\mathrm{CH}_{2} \mathrm{OH}$ 基のみを高選択的に酸 化して各々対応する $100 \%$ 鏡像異性体純度のラクトン 58〜65を好化学収率で得た（図21）。化合物 61 および 62 は各々グランジソールあるいはピレスロイド類の不 斎全合成シントンとして利用されよう。

$\operatorname{Sih} ら^{253}$ はメソーシス-2,4-ジメチルグルタル酸ジメ チルエステル（66）を $0.1 \mathrm{M}$ リン酸緩衝液中ブタ肝臓エ 


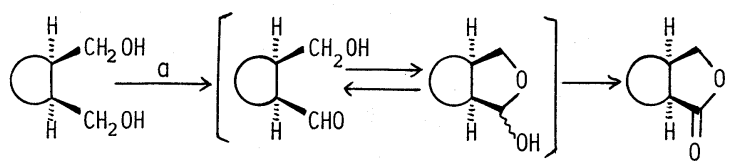

a:HLADH, NAD ,FMN, $\mathrm{pH} 9,20^{\circ} \mathrm{C}, 1 \sim 4$ days<smiles>O=C1OC[C@H]2CCCC[C@@H]12</smiles><smiles>O=C1OC[C@H]2CC=CC[C@H]12</smiles><smiles>O=C1OC[C@H]2CCC[C]12</smiles>

cy $72 \%$ ee $100 \%$<smiles>O=C1OC[C@H]2C[C@H]12</smiles>
cy $68 \%$ ee $100 \%$<smiles>C[C@H]1COC(=O)C1(C)C</smiles>

cy $64 \%$ ee $100 \%$ 64
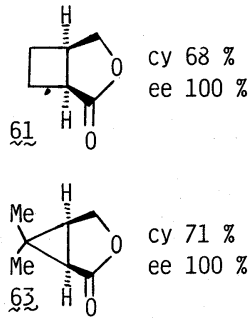

cy $71 \%$

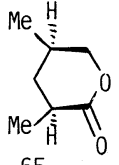

65 cy $65 \%$ ee $100 \%$ ee $100 \%$

ステラーゼ (PLE) と 60 分間インキュベートしモノエス テル 67 を $85 \%$ の化学収率で得ている。その絶対配置 は 67 の $\mathrm{LiBH}_{4}$ 還元によって立体構造既知のラクトン (2S, $4 R)-65$ に導き決定した。65 の鏡像異性体過剩率 (ee) は $\mathrm{Eu}(\mathrm{hfc})_{3}$ を用いた ${ }^{1} \mathrm{H}-\mathrm{NMR}$ 解析によって 64 $\%$ という低い值を示すにすぎなかった。この場合 PLE はジェステル 66 の $(S)$ 側のエステル基を優先的に加水 分解したことになる。次いで彼らは 66 のエナンチオ選 択的半加水分解を微生物を利用して検討した。数多くの 微生物を使用して種々試みたが究極的には Gliocladium roseum が高選択的に $(R)$ 側エステル基の加水分解を 触媒することを見出した。常法通りの反忘で得た環化成 績体 69 の光学純度は文献記載の $[\alpha]_{\mathrm{D}}$ の值から算出し て $98 \%$ 以上であることが明らかとなった（図 22 )。

大野ら ${ }^{26)}$ は酵素化学的アプローチによるヌクレオシド 関連化合物の不斉合成を行った。Diels-Alder 付加体 70 から導いた 71 を $10 \%$ アセトン- $0.1 \mathrm{M}$ リン酸緩衝液 中 PLEとインキュベートしたところ，96\%の化学収率 で光学活性モノエステル 72 が得られた。同様にエポキ シジェステル 73 む PLE とインキュベートすることによ り定量的に 74 に導かれている(図 23 )。化合物 72 はそ れぞれ独立した 2 つ反応経路によってリボフラノシド

Fig. 21

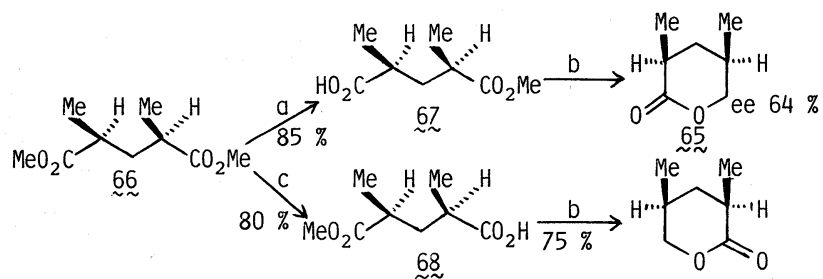

a:PLE, phosphate buffer( $\mathrm{pH} 8), \mathrm{Ih} ; \mathrm{b}: \mathrm{LiBH}_{4} ; \mathrm{c}:$ G. roseum

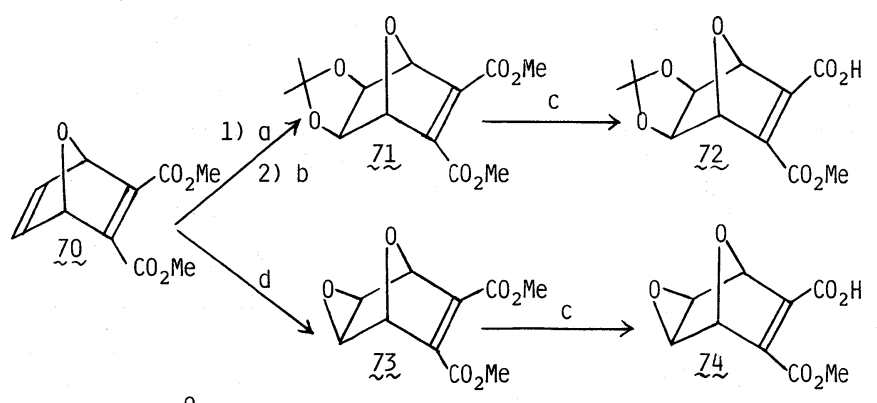

a: $0 \mathrm{SO}_{4}, \mathrm{Me}^{\mathrm{K}}-\mathrm{N} \mathrm{C} ; \mathrm{b}: \mathrm{MeO}_{\mathrm{MeO}}^{\mathrm{Me}}, \mathrm{MsOH} ; \mathrm{C}: \mathrm{PLE}, \operatorname{phosphate} \operatorname{buffer}(\mathrm{pH} 8)$, 30 32 ${ }^{\circ} \mathrm{C}, 4 \mathrm{~h}$; d:MCPBA

Fig. 23 
(+)-75(op=77\%)あるいはその対掌体 (一)-75(op $=95 \%)$ に “エナンチオ選択的”に導かれている。本エ ナンチオ選択的反応 $[(+)-75-71 \rightarrow(-)-75]$ は, 72 の前駆体 71 がメソ体といら対称分子であるからこそ容 易に達成されたものである。化合物 72 は数行程で効率 良くシュードマイシン (76) に導かれた。また，モノエ ステル 74 はコルディセピン (77) に導かれている。77 の光学純度は $77 \%$ であった。

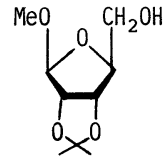

$(+)-75$

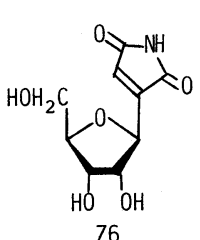

76

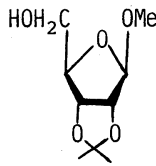

$(-)-75$

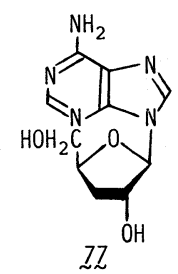

3.2. 純化学的方法による不斉誘導吉川ら ${ }^{20)}$ は メソ型環状ジカルボン酸無水物 78 および 80 を $\mathrm{Ru}_{2} \mathrm{Cl}_{4}$ $[(-) \mathrm{DIOP}]_{3}$ の存在下水素添加して低光学收率である が光学活性なラクトン 79 および 81 を得ている (図 24)。

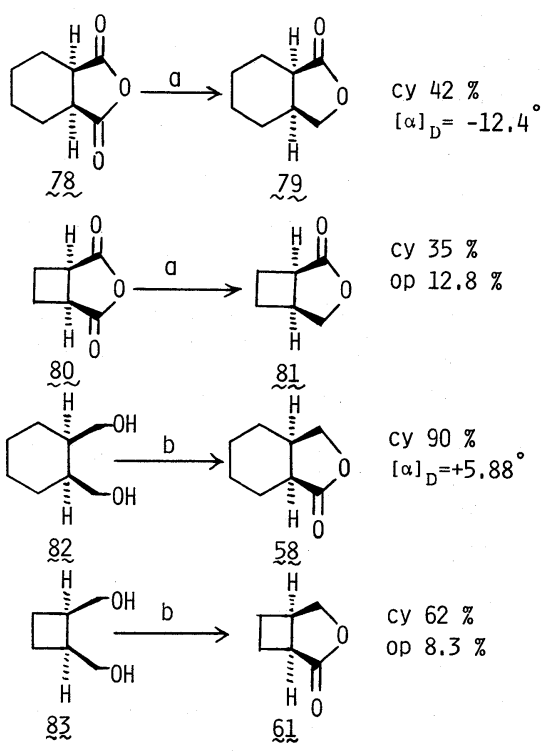

$\mathrm{a}: \mathrm{H}_{2}, \mathrm{Ru}_{2} \mathrm{Cl}_{4}\left[(-) \mathrm{DIOP}_{3}, \mathrm{Et}_{3} \mathrm{~N}\right.$, toluene, $100^{\circ} \mathrm{C}, 5 \mathrm{~h}$; $\mathrm{b}: \mathrm{Ru}_{2} \mathrm{Cl}_{4}\left[(-) \mathrm{DIOP}{ }_{3}, \mathrm{Et}_{3} \mathrm{~N}\right.$, toluene, $110^{\circ} \mathrm{C}, 2 \mathrm{~h}$

Fig. 24
さらに同氏ら ${ }^{21)}$ はメソ型 $1,4-$ 湆オール 82 および 83 を $\mathrm{Ru}_{2} \mathrm{Cl}_{4}[(-) \mathrm{DIOP}]_{3}$ 触媒による脱水素反応飞付し, 興 味あることに 79 および 81 の対掌体，ラクトン 58 およ び 61 を得ている（図24）。

筆者ら ${ }^{27,28)}$ はメソ-2, 4- ジメチルグルタル酸 (84) 関連 化合物に含まれる同一置換基中一方の純化学的手法によ る高位置選択的区別がまだ報告されていないことに着目し， 2. 2. で述べた $4(R)$ - MCTT 法を応用し種々検討した。 その結果, 極めて高度な位置および立体選択的区別が確 認された。その全反応操作は図 25 亿示した通りである。

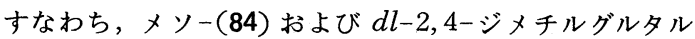
酸 (85) の混合物から既知の方法によって導いた酸無水 物 86 と 2 モル当量の $4(R)-\mathrm{MCTT}(42)$ を常法に従っ て縮合させ， $64.1 \%$ の収率で黄色油状化合物 87 を得た。 87 を $\mathrm{CH}_{2} \mathrm{Cl}_{2}$ 中 $-20^{\circ} \mathrm{C}$ で 1 モル当量のピペリジンと処 理すると，66.3\%の化学収率で 88 と 89 の混合成績体 が固体として得られた。88 と89 の生成比は HPLC 分 析にて $97.5: 2.5$ であることが明らかとなり，本不斉反 応は極めて高ジアステレオ選択的に進行していることが わかった。その固体状の混合成績体はただ一回の再結晶 で純粋な 88 の黄色板状晶となった。主成績体 88 の立 体化学はX線結晶解析によって決定された。副成績体 89 は量的に少なかったため別途に合成し，これを用い て 88 の場合と同様にX線結晶解析によってその立体化 学を明らかにした。化合物 88 を若干の求核反応剂との モニタ一反応に付し高収率で鏡像異性的に純粋な化合物 90〜93を得た。
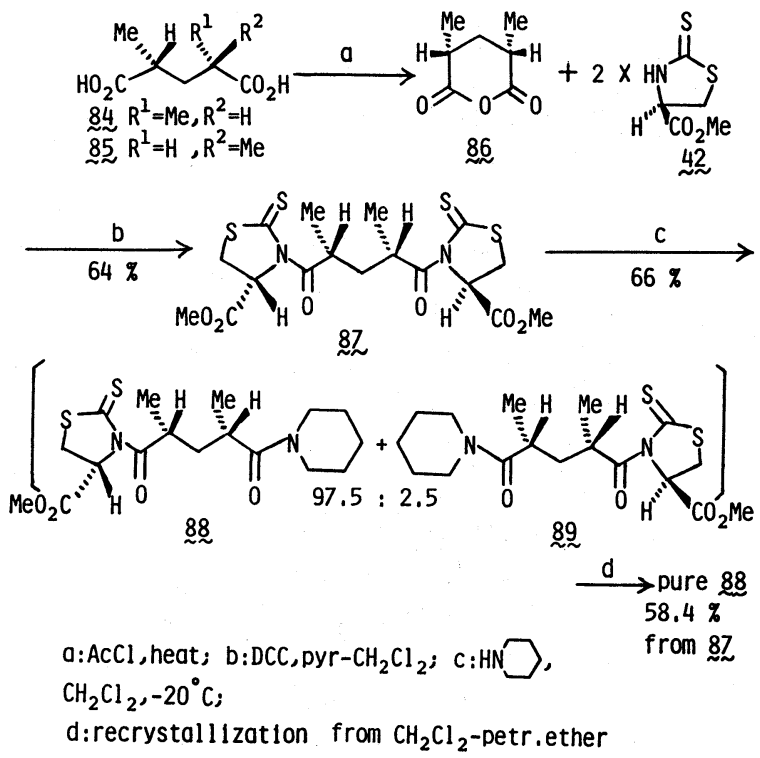

Fig. 25 


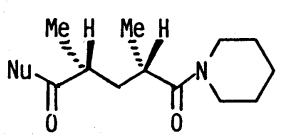

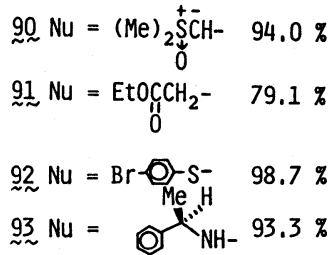

次いで筆者ら ${ }^{28)}$ は環状メソ化合物，メソー5-ノルボルネ ニレンーエンド-2,3-ジ酢酸 (94) ならびに準メソ化合物, シスー4-シクロヘキセニレンー1,2-ジ酢酸 (98)（実際は conformational enantiomer の等量混合物) への本手法 の発展拡大を試みた。その結果, 図”26, 図27に示したよ うに両者の場合，ともに高ジアステレオ選択的に不斉反 応が進行し，それぞれ主成績体 96 あるいは 100 が黄色 針状晶として得られた。96ならびに 100 の立体化学は ともにX線結晶解析によって決定された。以上, $4(R)-$ MCTT を活用する対称分子への新しい不斉誘導法の一 般化を確立することにより筆者らは次のような新概念を 確立することが出来た。すなわち，二官能性のプロキラ ルな対称分子中に 2 個の同一キラルリガンド，たとえば $4(R)$-MCTT 基を導入すると，その分子のもとの対称 性を非対称性に変えることが出来る。これは極めて応用 性の広い概念であり，新不斉合成法の分子設計に役立つ であろう。

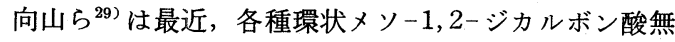
水物 102 と $(R)-($ - $-2-$ アミノ-2-フェニルェタノー ル(103) から 3 行程で導いたイミド 106 を還元し,さ
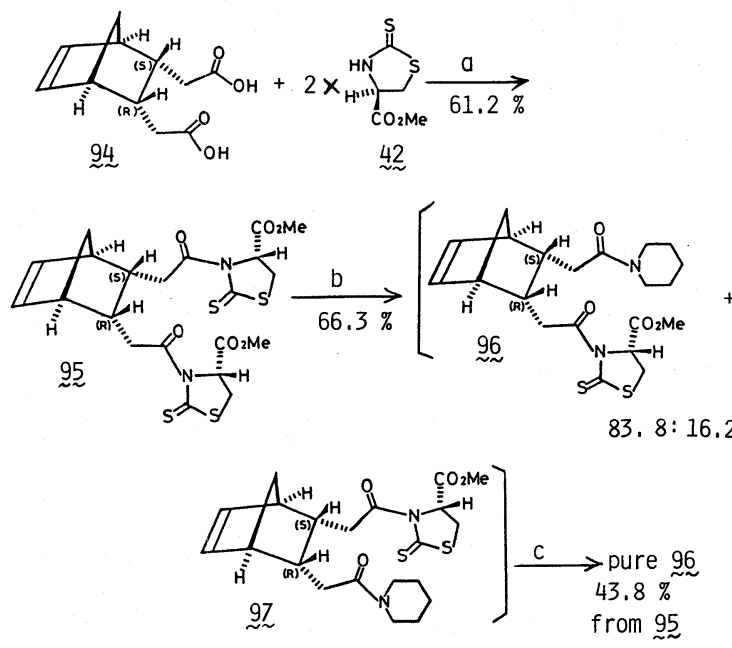

a:DCC, pyr; b:piperidine, $\mathrm{CH}_{2} \mathrm{Cl}_{2},-78^{\circ} \mathrm{C}$; C: recrystallization from hexane- $\mathrm{CH}_{2} \mathrm{Cl}_{2}$

Fig. 26
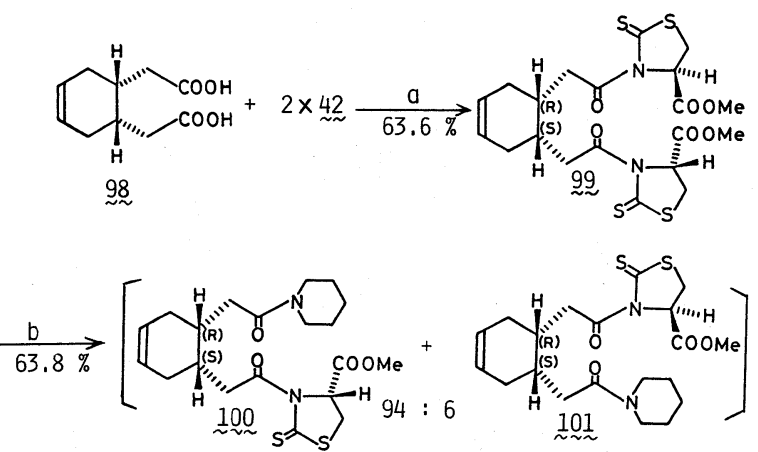

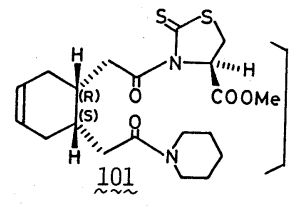

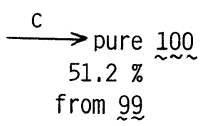

a:DCC, pyr; b: piperidine, $T H F,-78^{\circ} \mathrm{C}$; c: recrystallization from hexane- $\mathrm{CH}_{2} \mathrm{Cl}_{2}$

Fig. 27
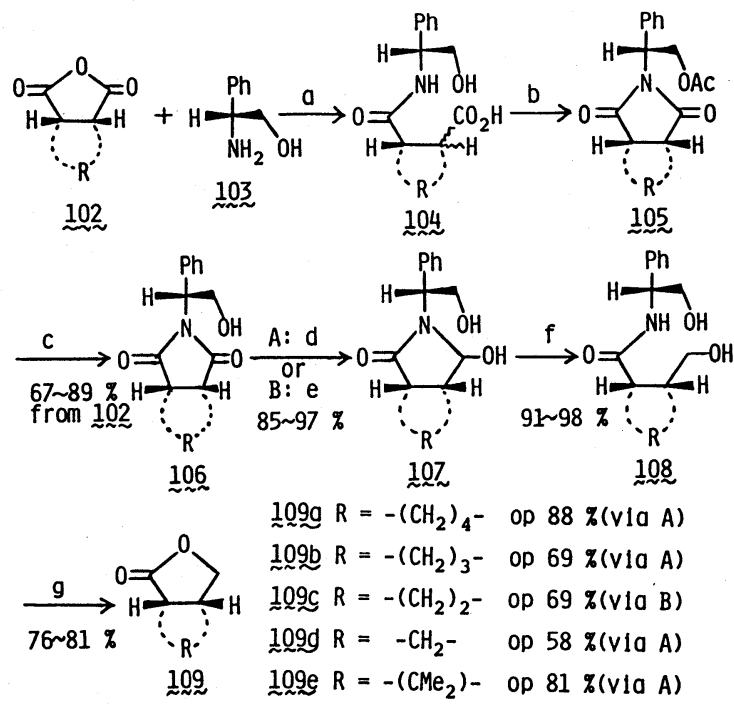

$a:$ THF, $0^{\circ} \mathrm{c}, 15 \mathrm{~min} ; \mathrm{b}: \mathrm{AC}_{2} 0, \mathrm{ACONa}, 100^{\circ} \mathrm{c}, 3 \mathrm{~h} ; \mathrm{c}: 1 \mathrm{~N}-\mathrm{HCl}, \mathrm{MeOH}$, reflux, $2 \mathrm{~h} ; \mathrm{d}: \mathrm{NaH}_{2} \mathrm{Al}(\mathrm{OMe})(\mathrm{OEt}),-42 \sim-100^{\circ} \mathrm{C}, 0.5 \sim 8 \mathrm{~h}$; e: $\mathrm{NaH}_{2} \mathrm{AlEt}_{2}, \mathrm{THF},-42 \sim-100^{\circ} \mathrm{C}, 0.5 \sim 8 \mathrm{~h} ; \mathrm{f}: \mathrm{NaBH}_{4}, 60 \% \mathrm{EtOH}, 50^{\circ}$ C, $4 \mathrm{~h} ; \mathrm{g}: 2 \mathrm{~N}-\mathrm{H}_{2} \mathrm{SO}_{4}, 80^{\circ} \mathrm{C}, 2 \mathrm{~h}$

Fig. 28

らに 2 行程の反応を経て光学活性な二環性 $\gamma$-ブチロラ クトン $109 \mathrm{a} \sim \mathrm{e}$ を得ている（図 28 )。本ジアステレオ 選択的還元反応の可能な反応機構として図 29 に示すよ うな経路が提唱されている。さらに同氏ら ${ }^{30)}$ は極く最 近, 4 種のメソ-1,2-ジオール類 110 の不斉アシル化反 応を報告している。すなわち，ジオール110 と酸化ジブ 


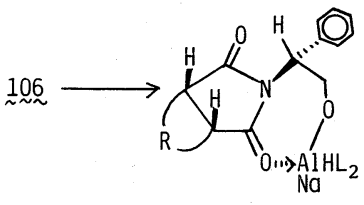

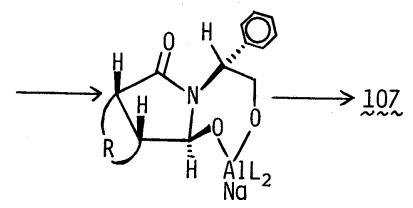

Fig. 29

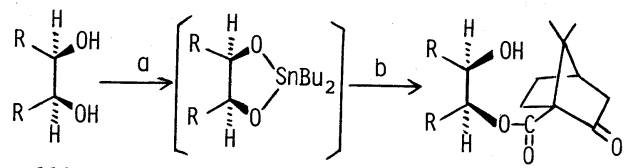

$\frac{110}{\sim \sim}$<smiles>CC1(C)C2CCC1(C(=O)Cl)CC(=O)C2</smiles>

112

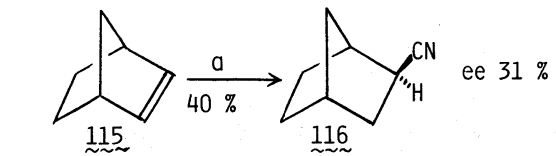

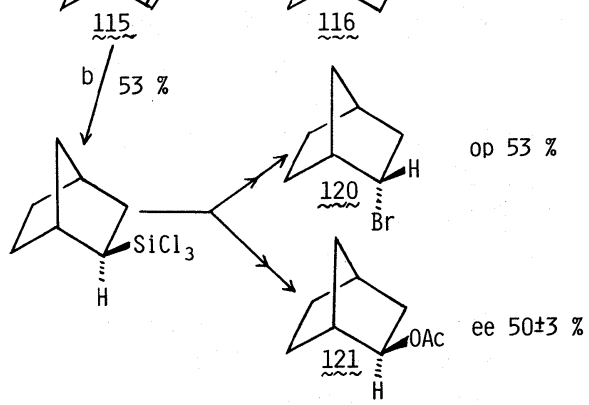<smiles>C1=CC2CCC1C2</smiles>
$\underset{\sim \sim 2}{117}$

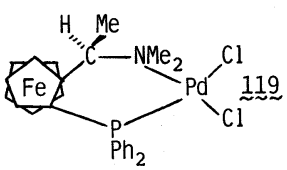

$\mathrm{a}: \mathrm{HCN}, \mathrm{Pd}\left[(+) \mathrm{DIOP}\right.$, benzene, $80^{\circ} \mathrm{C} ; \mathrm{b}: \mathrm{HSiCl}_{3}$, compound $\underset{\sim \sim}{119}, 70^{\circ} \mathrm{C}, 40 \mathrm{~h}$

Fig. 31

るいは 121 への不斉反応を報告している（図31）。

4. おわりに

チルスズの混合物をモレキュラシーブ $4 \mathrm{~A}$ 存在下加熱還 流する。その反応混液に 1.3 モル当量の $d$-ketopinic acid chloride (112) トルエン溶液を $0{ }^{\circ} \mathrm{C}$ (場合によっ ては室温まで温度をあげる) で加え反応させ，ジアステ レオ選択的にモノエステル $111 \mathrm{a} \sim \mathrm{d}$ を高化学収率で得 ている。

寺島ら ${ }^{31)}$ は対称的に官能基を有するメソ化合物 113 を 光学分割の基質として採用し, “エナンチオ選択的”かつ “エナンチオ集合的”な反応経路を官能基変換による手 法で確立し，光学活性のプロスタグランジン全合成中間 体 114 の合成に成功している。同様の巧みな合成戦略は シスー2-シクロヘキセン-1,4-ジオールにおいても達成 されている32)。

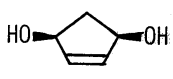

113

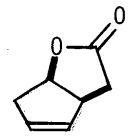

$(+)-\frac{1}{2} 14$

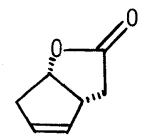

(+) -1114

Jackson ら ${ }^{33)}$ はノルボルネン(115) から 116 人，そ してノルボルナジェン (117) から 118 へのエナンチオ選 択的変換を報告しており，熊田ら ${ }^{34)}$ も115から 120 あ

33 


\section{文献}

1) D. Enders, Chemtech, 11, 504 (1981)

2) 森 謙治, 化学と生物, 20, 84 (1982)

3） $\mathrm{sp}^{3}$ プロキラル中心を有する化合物のみならずメ

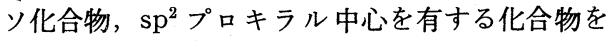
も含めてプロキラル化合物と総称される。しかし 本稿では $\mathrm{sp}^{2}$ プロキラル中心をもつ化合物を議論 の対象とせず除外する。

4) 藤田榮一，化学の領域，36，888 (1982)

5) 長尾善光, ファルマシア, 19, 179 (1983)

6) S. Takano, K. Seya, E. Goto, M. Hirama, K. Ogasawara, Synthesis, 1983, 116

7) Y.Tsuda, K. Yoshimoto, T. Nishikawa, Chem. Pharm. Bull., 29, 3593 (1981)

8) S. G. Cohen, L. H.Klee, J. Am. Chem. Soc., 82, 6038 (1960)

9) S. G. Cohen, E. Khedouri, ibid., 83, 1093 (1961) ; idem, ibid., 83, 4228 (1961)

10) C. Bally, F. Leuthardt, Helv. Chim. Acta, 53, 732 (1970) ; B. Hadorn, F. Leuthardt, E. Ménard, D. Vischer, ibid., 46, 2003 (1963)

11) A. J. Irwin, J. B. Jones, J. Am. Chem. Soc., 99, 556 (1977)

12) F. - C.Huang, L. F. H. Lee, R. S. D. Mittal, P. R. Ravikumar, J. A. Chan, C. J.Sih, E. Caspi, C.R.Eck, ibid., 97, 4144 (1975)

13) H. Ohta, H. Tetsukawa, Agric. Biol. Chem., 45, 1895 (1981); idem, Chem. Lett., 1979, 1379

14) M. Ohno, S. Kobayashi, T. Iimori, Y.-F. Wang, T. Izawa, J. Am. Chem. Soc., 103, 2405 (1981); K. Okano, T. Izawa, M.Ohno, Tetrahedron Lett., 24, 217 (1983) ; T. Iimori, Y. Takahashi, T. Izawa, S. Kobayashi, M. Ohno, J. Am. Chem. Soc., 105, 1659 (1983)

15) P.Schwartz, H.E. Carter, Proc. Natl. Acad. Sci., 40, 499 (1954)

16) R. Altschul, P. Bernstein, S. G. Cohen, J. Am. Chem. Soc., 78, 5091 (1956)

17) 藤田榮一, 長尾善光, 有合化, 38, 1176 (1980)

18) E. Fujita, Pure Appl. Chem., 53, 1141 (1981); 長尾善光, 薬学雑誌, 102, 401 (1982); Y. Nagao, K. Seno, K. Kawabata, T Miyasaka, S.
Takao, E. Fujita, Tetrahedron Lett., 21, 841 (1980); Y. Nagao, S. Takao, T. Miyasaka, E. Fujita, J. Chem. Soc., Chem. Commun., 1981, 286 ; E. Fujita, Y. Nagao, K. Seno, T. Miyasaka, M. Kimura, W. H. Watson, J. Chem. Soc., Perkin Trans. 1, 1981, 914

19) Y.Nagao, T. Ikeda, M. Yagi, E. Fujita, M. Shiro, J. Am. Chem. Soc., 104, 2079 (1982)

20) K. Osakada, M. Obana, T. Ikariya, M.Saburi, S. Yoshikawa, Tetrahedron Lett., 22, 4297 (1981)

21) Y. Ishii, K. Osakada, T. Ikariya, M. Saburi, S. Yoshikawa, Chem. Lett., 1982, 1179

22) U.Eder, G. Sauer, R. Wiechert, Angew. Chem. Intern. Ed. Engl., 10, 496 (1971)

23) Z.G.Hajos, D. R.Parrish, J. Org. Chem., 39, 1615 (1974)

24) I. J. Jakovac, H. B. Goodbrand, K. P. Lok, J. B. Jones, J. Am. Chem. Soc., 104, 4659 (1982); I. J. Jakovac, G. Ng, K. P. Lok, J. B. Jones, J. Chem. Soc., Chem. Commun., 1980, 515 ; H. B. Goodbrand, J. B. Jones, ibid., 1977, 469

25) C. -S. Chen, Y.Fujimoto, C. J.Sih, J. Am. Chem. Soc., 103, 3580 (1981)

26) Y.Ito, T. Shibata, M. Arita, H. Sawai, M. Ohno, ibid., 103, 6739 (1981)

27) Y.Nagao, T.Inoue, E. Fujita, S. Terada, M. Shiro, J. Org. Chem., 48, 132 (1983)

28) idem, Tetrahedron Symposia-in-print, in press

29) T.Mukaiyama, H. Yamashita, M. Asami, Chem. Lett., 1983, 385

30) T.Mukaiyama, I. Tomioka, M.Shimizu, ibid., 1984, 49

31) S. Terashima, S. Yamada, Tetrahedron Lett., 1977, 1001

32) S. Terashima, M. Nara, S. Yamada, ibid., 1978, 1487

33) P.S.Elmes, W. R. Jackson, J. Am. Chem. Soc., 101, 6128 (1979)

34) T.Hayashi, K. Tamao, Y. Katsuro, I. Nakae, M.Kumada, Tetrahedron Lett., 21, 1871 (1980)

35）福井三郎, 田中渥夫, 有合化, 41，384 (1983) 